\title{
The Story of the Mont Blanc Observatories.
}

\author{
By Dr. A. E. H. Tutron, F.R.S.
}

THE announcement of the death of Joseph Vallot, 1 the founder and director of the permanent observatory on Mont Blanc, at the age of seventy-two years, at his residence in Nice, will doubtless render the following account of some special interest. After I had made a particularly memorable ascent to the summit of Mont Blanc in magnificent weather on August 9, 1923, spending some time, both on the ascent and on the return to Chamonix, at the most welcome refuge and observatory of M. Vallot on the rocks of the Rocher des Bosses, at the height of I4,3 I 2 feet-it was obvious that the veteran mountaineer and scientist was in failing health-I was fortunately able to persuade M. Vallot to put the salient facts regarding the Mont Blanc observatories in writing. M. Vallot responded most kindly, and prepared a typed and signed statement, which is now of such interest and importance that it has been freely translated and embodied, with some additional facts of earlier date, in the following account. Indeed, M. Vallot gave special permission, almost a request, that its essence might be contributed either to NATURE or to the Royal Astronomical Society, and it is with great pleasure that this account is now at last written, although the sad circumstance of M. Vallot's passing from the magnificent scene of his life-work on Mont Blanc, in the valleys around which he will be greatly missed as a munificent friend and benefactor, renders the occasion one which the scientific world will deplore.

The summit of Mont Blanc, the highest point of Europe, 15,782 feet high, is a dome of snow absolutely unbroken by rock of any shape or kind. It is large enough to accommodate three or four parties of climbers at a time, of not more than four on each rope. When M. Eiffel made his celebrated sounding of its depth, for the purpose of deciding how the summit observatory of M. Janssen was to be erected, he excavated a tunnel or trench 150 feet long and 50 feet deep without touching anything but snow and hard ice, so that the depth of the snow cap must be immense.

It will be recalled that Mont Blanc was climbed for the first time by Jacques Balmat and Dr. Paccard (who reached the summit perhaps an hour after Balmat) on August $8, \mathbf{I} 786$, ascending by the Montagne de la Côte, where they spent the night at the edge of the glacier, the Grand Plateau, and the Rocher Rouge. The next year it is a tradition that Balmat again ascended it on July 5, with two Chamoniards, Cachat and Tournier. But whether that be fact or not, on August I, 2, and 3, ${ }_{17} 87$, Balmat conducted to the summit the well-known savant H. B. de Saussure, accompanied by his valet and eighteen guides, mostly laden with scientific apparatus. They reached the summit about II A.M. on August 3, and stayed there four hours while de Saussure carried out some of his contemplated experiments. But the whole party were grievously afflicted with mountain sickness. Indeed, very few of those who ascend Mont Blanc escape after passing the i2,000 feet level, as the writer, who only suffered from it once before in twenty-five years of climbing, can well testify. Next year, I788, de Saussure more or less completed his experiments at a lower level, in a hut on the Col du Géant, where he spent fifteen days.

In 1844 Prof. Bravais (so well known as the pioneer of our knowledge of space-lattices in crystals), with MM. Martins and Le Pileur, reached the summit, on August $\mathrm{I}_{7}$, and spent five hours in making observations.

In $185^{8}$ Prof. Tyndall ascended Mont Blanc and placed a thermometer with an iron stem four feet deep in the ice, in order to attempt to measure the winter cold. On August 2r, I859, he again made the ascent, accompanied by Prof. Frankland (afterwards Sir Edward), but they could not even find the thermometer. A second attempt failed through the thermometer being found broken. On this 1859 ascent the effects of solar radiation and of height on the rate of combustion were studied. Six candles were weighed at Chamonix, burnt for an hour in the Hotel de l'Union, and the loss of weight determined. The same candles were taken to the summit of Mont Blanc, and allowed to burn for an hour in a protective tent. The aspect of the flame surprised them, for it was " but the ghost of what it had been at Chamonix," being enlarged, pale, and feeble, suggesting diminished energy of combustion. Yet when the candles were weighed again after returning to Chamonix, it was found that the loss was almost exactly the same as before. The result was due to the greater mobility of the air at this great height, the oxygen molecules making up for their smaller numbers by their increased rapidity of movement.

Scientific observations were afterwards made on the summit by Prof. Hodgkinson on July r4, 1866, by Prof. Soret of Geneva on July 21, 1867, and on August 6, I875, by M. Jules Violles of Grenoble, the last mentioned finding the temperature of the sun's rays to be $4^{\circ} \mathrm{C}$. higher at the summit than at the foot of the Bossons glacier.

The ice movements at the summit were thus early recognised by Prof. Tyndall, whose thermometer must have moved some considerable distance. It reminds one of a statement by Capt. Sherwill, who, with Dr. E. Clarke, climbed the mountain in 1825 , that Napoleon ordered a cross to be erected on Mont Blanc, and his command was carried out by Jean Marie Coutet. But the cross only remained erect for four hours, and in four days was thrown down and had entirely disappeared.

M. Joseph Vallot made his first ascent of Mont Blanc in 1880 , purely as a climber. But in 1886 he returned to Chamonix, and made his first scientific expedition to the summit. The next year, 1887 , he made another expedition and stayed three days on the summit, under a simple canvas tent, a feat of great hardihood which would have become tragic if the weather had changed from the fine spell. He obtained most valuable scientific results on this occasion, and decided to endeavour to continue them another summer in some more efficient protective building. In 1890 , with the aid of more than a hundred guides who offered assistance, and a very small financial contribution from the Commune, he constructed the first observatory on the highest rock, which appeared to his judgment to offer 
a good foundation for a durable edifice. It was a little flat rock, almost on the level of the snow, which goes down very steeply on the Italian (Courmayeur) side, in the little Col between the present refuge hut and the Grand Bosse du Dromadaire. The observatory proved immediately useful for experiments, and was enlarged twice, in the succeeding summers of 1891 and 1892 . It was at a height of about $I_{3,500}$ feet, measured about I 6 by ro feet, and was about ro feet in height. It was divided into two portions, one for observers and the instruments, and the other as a refuge for climbers. Shortly afterwards, the climbing portion became such a nuisance to the observers that $M$. Vallot, at his entire expense, constructed the present separate refuge hut on the Rocher des Bosses at an altitude of I4,3 I2 feet.

Unfortunately the little flat rock on which the observatory was built proved not to be the ideal spot which it was hoped it would be; the snow-field mounted up to it little by little, and ended by enveloping the little wooden structure up to the roof, rendering it unsanitary and almost uninhabitable. M. Vallot, however, was not discouraged, but, again entirely at his own expense, had a suitable foundation blasted in a part of the Rocher des Bosses, near to the refuge hut, and re-erected his observatory there, the work lasting fortyfive days of the summer of 1898 . The new building, constructed on a rock with a good escarpment, could not possibly be buried in the snow, and after twentyseven years still defies the terrible tempests which break so suddenly and so often over this mountain. Each year it has afforded to scientists who desired to use it, after arranging with $M$. Vallot, a safe and relatively, remembering the position, most comfortable shelter in which to conduct their experiments.

Prof. P. J. C. Janssen, of Paris, the well-known astronomer, made an expedition to the Vallot observatory in 1890 , and while there conceived the project of establishing an observatory of his own on the snow of the summit itself, in spite of the advice of M. Vallot, who tried to make him see that it is impossible to construct anything of stability on a glacier. M. Vallot says in a letter to the writer: "Janssen était un grand astronome, mais il ne connaissait les glaciers, et il a eu tort de ne pas vouloir écouter ceux qui les connaissaient. Il a voulu lutter contre le glacier, contre la nature ; ce n'était pas possible, et il a eu un échec retentissant." At the request of $M$. Eiffel, M. Vallot lodged in his observatory the engineers and workmen sent by $\mathrm{M}$. Janssen, and the observatory on the summit was constructed in 1893 . A large telescope with $30-\mathrm{cm}$. objective was installed; but it was never possible to use this beautiful instrument on account of the instability of the glacier base. The meteorograph, constructed to work automatically, became frozen and entirely stopped in a few days. Hence, the observers had to be content with making studies in physics and astronomical physics, analogous to those which had been carried on continuously in the Vallot observatory. An expenditure of no less than 300,000 francs (then $12,000 l$.) had been incurred, furnished by public-spirited and scientific subscribers, to obtain very slight results.

Almost as soon as it was constructed, the summit observatory commenced to sink in the snow, which began to hold it as in a cup. The building was of two storeys and about 23 feet high, and the roof formed a kind of outlook-platform, approached by a spiral stairway in a little tower. In I900 the platform had sunk to the level of the snow of the summit, and to prevent the building being engulfed altogether, the snow around it had to be excavated away each year, in order that the upper storey might be used. But this labour soon became too considerable, and was given up in 1906. The snow then mounted over the roof, and in I908 had covered it for a depth of more than a yard, leaving only just visible the top of the tower.

M. Janssen died in 1907 , and as some funds remained a committee of management was formed, and $M$. Vallot was made director. In I9o8 a delegation met on the summit, and certified that the observatory was buried, deformed, and breaking up. It was decided to abandon it, and the instruments were brought down. At the suggestion of $M$. Vallot the salvage of the debris was decided on, and in ' 1909 it was dug out and transported, more or less piecemeal, to the Col des Bosses, near to the spot where M. Vallot had erected his first observatory, where it is being gradually used for firewood for the Vallot observatory and hut. The observers sent by the Committee were accommodated by M. Vallot in his observatory, which appears to be now well off for fuel, formerly a very grave difficulty.

When the present writer reached the Col des Bosses on August 9, I923, the first thing that attracted his attention was the remains of the Janssen observatory, lying clearly marked on the snowfield. A few further particulars were afforded him by M. Paul Cupelin, guide chef of Chamonix. According to the latter the summit observatory, just before being dug up, had begun to work its way out towards the Chamonix side of the mountain; its transport had been a very difficult matter, the whole of the parts being entirely carried 2300 feet of descent on the backs of porters and with the help of ropes fastened to posts driven into the steep snow slope.

The Committee was very unwilling to abandon the summit, and suggested to M. Vallot that he should utilise part of the debris to construct a small light laboratory on the summit, capable of being brought to the surface each year. M. Vallot consented, but with much misgiving. He had the little hut erected, but warned the Committee that it would not be safe against thunderstorms. The next year M. Vallot's people were able to relieve it from the submerging snow, but unfortunately his warning was but too soon verified, for an expedition which had imprudently stayed in the laboratory too long were caught in a violent thunderstorm and a member of the party was killed by lightning in the hut. The next year, I9r2, no workmen could be found willing to dig out the laboratory, which was deeply submerged in snow. In I9I3 it had entirely disappeared, and soundings and borings made to locate it failed to find any trace of it. Doubtless, some day, this second summit observatory will work its way out to the Chamonix side, towards which the ice movement appears to be especially directed, and remind the world of its fugitive, useful existence. M. Vallot's predictions were thus once more remarkably verified.

The impression that appears to have been current, that observers spent the year in the Janssen laboratory, is, of course, quite wrong. It was only habitable for

$$
\text { NO. 2899, VOL. I I } 5]
$$


the short summer season, from the middle of June to the middle of September, the usual climbing season. The observers prepared all their experiments in the valley, made the ascent and possibly stayed two or three days, and then descended. The Vallot observatory is visited every year by young science graduates sent out by the Société des Observatoires, and regular memoirs are printed and published. Indeed, there is usually a waiting list of young savants eager for places in the observatory, which is remarkably comfortable considering the height. Fortunately it is likely that some members of M. Vallot's family will continue the good work, and it is only right that every credit should be given to the great and generous man, great in every sense of the word, who in I920, at the age of sixty-six, made his thirty-fourth and last expedition to the summit of Mont Blanc, and has just passed away amid the deepest regret.

\title{
Soaps and the Theory of Colloids. ${ }^{1}$
}

\author{
By Prof. J. W. McBain, F.R.S.
}

$\mathrm{T}^{\mathrm{H}}$ subject of colloids has suffered from an excess of conflicting speculations in the absence of precise and definite experimental evidence. It is still found difficult to devise methods of experiment which will yield exact, and also unambiguous, results.

At the time when we began work in this field one of the chief recognised characteristics of colloids was their changeability and the dependence of their behaviour upon the vagaries of individual specimens. The object was thoroughly to study one typical colloid in order to supply the definite evidence required for testing or building up the theory of the subject. No general theory can be true which is incompatible with carefully established experimental evidence obtained with any one typical material.

Our chief experience is that the more carefully the colloid is studied the less colloidal it is found to be. Soap is a unique material for the investigation of colloidal phenomena, because it illustrates nearly all the behaviour found in other colloidal systems, and it is one of the few common reversible colloids which have a definite, simple, known chemical formula. Last and most important, all results with soap solutions are quantitatively reproducible, and, in the many cases where our results have been tested in other laboratories, the experimental data have always been confirmed. We have been able to find one precise relationship after another, so that the results are almost lifted out of the colloidal field. Nevertheless it remains true that soaps are typical colloids, and that the results are of general significance in determining the behaviour of colloids and their relationship to other states of matter.

Soaps exhibit an apparently inexhaustible variety of behaviour, and few days pass without some new and interesting observation being made. A great deal of incidental information is obtained in the quest. For example, under certain conditions twice as much soap is required for a given amount of detergent action if the soap solution is allowed to stand for a day before use. Again, Miss Laing has carried out analyses which show that the substance which accumulates in the surface of soap solutions and of soap films is not free fatty acid but an acid sodium soap, a very slight excess of alkalinity in the soap solution converting it all to neutral sodium or potassium soap.

Soap is important as a type of a great class of substances known as colloidal electrolytes. It is essential to examine carefully the evidence obtained by a study of ordinary solutions of soap, since from it follows directly a proof of the micellar theory. The essence of

1 Discourse delivere 1 at the Royal Institution oa Friday, March 20.

$$
\text { No. } 2899 \text {, VOL. I I } 5 \text { ] }
$$

the micellar theory is that not the chemical molecules but aggregates of particles are the colloidal units.

It is necessary to show that hydrolysis, although always present to a slight extent, does not account for the major properties of the solutions. There are only traces of free fatty acid present, and there is but little free alkali, far less than in sodium carbonate; this has been shown by half a dozen independent quantitative methods. Hydrolysis is only of importance in dilute solutions. This is borne out by the fact that the hydrogen soap, cetyl sulphonic acid, has properties exactly parallel to ordinary soap in concentrated solution. Hence the major properties of a strong soap solution are due to the soap itself.

We have found that in dilute solution, soaps are ordinary crystalloids, just like common salt, and dissociate into sodium and potassium ions and simple fatty ions. Upon concentrating the solutions, however, the undissociated soap molecules aggregate to form large particles of neutral soap; that is, neutral micelles. Likewise the fatty ions unite in small groups to form a new type of particle-the ionic micelle-in which there is one free charge for each fatty ion. By changing the concentration or the temperature, all intermediate proportions of these constituents can be produced. This may be summarised in the following scheme :

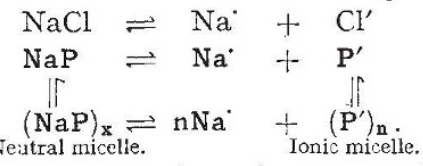

The evidence for the foregoing conception is based upon a study of osmotic effects and of electrical conductivity. The osmotic effects as exemplified by the lowering of freezing point, of dew point, and of vapour pressure, and also the minimum pressure required for ultrafiltration, are in general half the values to be expected for the same concentrations of a typical salt such as sodium acetate. On the other hand, the conductivity of concentrated solutions is fully equal to that of sodium acetate. A large mass of data obtained chiefly in the laboratories of the University of Bristol has established both these truths.

If now the whole of the osmotic effect be taken as a measure of the sodium ions present, thus leaving no other crystalloidal constituent, rather less than half of the observed conductivity is accounted for. The other half of the conductivity must be due to colloidal constituents, and one of these constituents must have the same number of negative charges as there are positive ions: this is the ionic micelle. The undissociated 